\title{
Gastrointestinal Stromal Tumour in a Guinea Pig: a Case Report
}

\author{
František Jelínek ${ }^{1}$, Pavel Hron², Františka Hozmanová ${ }^{2}$ \\ ${ }^{1}$ Veterinary Histopathological Laboratory, Prague, Czech Republic \\ ${ }^{2}$ Veterinary Clinic Erika, Prague, Czech Republic
}

Received May 27, 2008

Accepted February 9, 2009

\begin{abstract}
The objective of this contribution was to present a case report of gastrointestinal stromal tumour (GIST) in one guinea pig: a pet animal, male, 3.5 year of age, tricolour. Approximately for five weeks before death wasting, in spite of good appetite, decreased locomotor activity, soft and malodorous faeces were observed by the owner. The animal spontaneously died and at necropsy a grey-pink coloured tumour of walnut size located in the terminal segment of the ileum was observed. A solid malignant tumour of mesenchymal appearance was diagnosed histologically. One part of the sample consisted of tightly packed spindle cells arranged in interlacing fascicles, in the other part epithelioid cells predominated with slightly myxoid intercellular matrix. Lymphocytic sheaths were observed around some blood capillaries. Immunohistochemistry revealed positivity for actin, CD 117, neuron-specific enolase, glial fibrillary acidic protein, and p53 protein; however, desmin, S100 protein and synaptophysin were negative. On the basis of histological and immunohistochemical examinations GIST was diagnosed.
\end{abstract}

Intestine, neoplasia, interstitial cells of Cajal, GIST

Ramon y Cajal described special cells located in the vicinity of the neuronal plexuses at first in 1889 and later in 1893 and 1911 (Kobayashi et al. 1989). He supposed their function in the regulation of gut peristalsis. Later these cells were called interstitial cells of Cajal (ICC). By the end of 1980s and during 1990s some authors, e.g. Kobayashi et al. (1989), Ward et al. (1994), Huizinga (1995), Ordög et al. (1999) proved that ICC generate impulses of motoric automatism similarly as in the myocardium. The most recent results demonstrate that ICC located in the myenteric plexuses and in submucosa really possess a pacemaker function, whereas ICC situated in the interstitium of the lamina muscularis transmit signals from neurons to smooth muscle cells (Mitsui and Komuro 2003; Iino and Horiguchi 2006; Lee et al. 2007). A tumour arising from ICC is named the gastrointestinal stromal tumour (GIST), and is considered as a low-grade sarcoma harbouring mutation of c-kit. GIST was first described in humans in the 1980s, and the term GIST was first coined by Mazur and Clark in 1983 (Ozcan et al. 2007). Banerjee et al. (1991) have described GIST in two Rhesus macaques (Macaca mulatta), Del Piero et al. (2001) and Hafner et al. (2001) diagnosed it in horses, and Frost et al. (2003) characterized and analyzed 29 cases of GIST in dogs. To the best of our knowledge, the histogenesis of a tumour of ICC has not been described in a guinea pig until now. For this reason we publish our observation.

\section{The animal}

\section{Case description}

Guinea pig, male, 3.5 year of age, tricolour, was kept as a pet animal in a household. Approximately for five weeks before death wasting, in spite of good appetite, decreased locomotor activity, soft and malodorous faeces were observed by the owner. Veterinary clinician revealed by palpation a globoid formation of walnut size in the abdominal cavity. Some days later the animal died spontaneously.

Address for correspondence:

Prof. MVDr. František Jelínek, CSc.

Veterinary Histopathological Laboratory

Sojovická 16

19700 Prague 9, Czech Republic 


\section{Gross pathology}

Necropsy was performed by the veterinary clinician. Apart from mild hydrothorax, ascites and atelectasis in the part of the pulmonary lobes, a tumour of grey-pink colour that grew from the terminal segment of the ileum was observed (Plate IX, Fig. 1). Inside the neoplastic formation a cavity communicating directly with lumen of the bowel was found, filled with intestinal contents. No other pathological changes were macroscopically obvious. A sample of the neoplasia was submitted to histopathological examination.

\section{Methods of histopathological examination}

The sample was fixed in $10 \%$ buffered formalin and processed by the common paraffin wax method. Histological sections $5 \mu \mathrm{m}$ thick were stained with haematoxylin and eosin. Immunohistochemical examination was performed by means of a common immunoperoxidase method on paraffin wax sections attached to slides treated with 3-aminopropyltriethoxysilane (Fluka Chemie AG). After the usual deparaffinisation the antigens were unmasked by boiling in $0.1 \mathrm{~mol} / 1$ citrate buffer, $\mathrm{pH} 6.0$ for $10 \mathrm{~min}$, and endogenous peroxidase acitivity was eliminated with $3 \%$ hydrogen peroxide for $15 \mathrm{~min}$ at room temperature. Non-specific binding was suppressed with Protein Blocking Agent (Immunotech) for 5 - $7 \mathrm{~min}$ at room temperature. The list of primary antibodies manufactured by DakoCytomation is given in Table 1. Histological sections were incubated with primary antibodies in a humidified chamber for $60 \mathrm{~min}$ at room temperature. Visualisation of the reaction was done by means of UltraTech HRP set (Immunotech) and UltraTech DAB set (Immunotech). The slides were counterstained with haematoxylin, dehydrated and mounted in Canada balsam.

Table 1. Antibodies, their specification and dilution

\begin{tabular}{|c|c|c|}
\hline Antibody & Clone & Dilution \\
\hline Muscle Actin & HHF35 & $1: 50$ \\
\hline CD117, c-kit & polyclonal & $1: 100$ \\
\hline Desmin & D33 & $1: 50$ \\
\hline Glial fibrillary acidic protein & polyclonal & $1: 100$ \\
\hline Neuron-specific enolase & BBS/NC/VI-H14 & $1: 100$ \\
\hline p53 protein & DO-7 & $1: 50$ \\
\hline Synaptophysin & SY38 & $1: 100$ \\
\hline S100 protein & polyclonal & $1: 300$ \\
\hline
\end{tabular}

\section{Results of histopathological examination}

A solid tumour of mesenchymal appearance was observed. One part of the sample consisted of tightly packed spindle cells arranged in interlacing fascicles. In the other part epithelioid cells predominated with slightly myxoid intercellular matrix. Marked anisokaryosis, oval, cigar-shaped or irregular nuclei with fine chromatin were found in the neoplastic cells. In a majority of the nuclei, especially in the large and light ones, the nucleoli were clearly apparent. On average four mitotic figures were found per one high-power field (in the range of 2-7) and a number of them were atypical. Cytoplasm of the neoplastic cells was lightly basophilic, reticular or finely vacuolated with indistinct cellular boundaries. There were also many neoplastic cells that exhibited signs of apoptosis. Lymphocytic sheaths were observed around some blood capillaries (Plate IX, Fig. 2, Plate X, Fig. 3, 4) Results of immunohistochemical examination are summarized in Table 2 and demonstrated in Figs Plate XI, Figs 5, 6, Plate XII, Figs. 7, 8.

\section{Discussion}

Gastrointestinal stromal tumour (GIST) was first described in humans in the 1980s as a non-lymphomatous, non-epithelial tumour of the gut and the term GIST was first coined by Mazur and Clark in 1983 (Ozcan et al. 2007). LaRock and Ginn (1997) included in GIST the diagnosis of leiomyoma, leiomyosarcoma, neurofibrosarcoma and 
Table 2. Results of immunohistochemical examination

\begin{tabular}{|l|c|c|c|}
\hline Antibody & Nuclei & Cytoplasm & Comment \\
\hline Actin & - & ++ & Majority of the cells \\
\hline CD 117 (c-kit) & - & $++/+++$ & $\begin{array}{c}\text { Majority of the cells, marked positivity } \\
\text { in the epithelioid cells }\end{array}$ \\
\hline Desmin & - & - & Marked positivity in the epithelioid cells \\
\hline GFAP & $++/++$ & $++/++$ & Majority of the cells \\
\hline NSE & - & +++ & Positivity predominantly in the nuclei \\
\hline p53 & $+/+$ & ++ & \\
\hline Synaptophysin & - & - & \\
\hline S100 protein & - & - & \\
\hline
\end{tabular}

undifferentiated sarcomas. In the opinion of Cooper and Valentine (2002), the term GIST, of which leiomyoma and leiomyosarcoma are the most common subsets, is the most appropriate designation. On the other hand, by means of immunohistochemical examination, Sircar et al. (1999) classified 43 gastrointestinal mesenchymal tumours in humans into eight myoid tumours, one schwannoma, and 34 GIST. Head et al. (2003) characterize GIST as a neoplasm presumed to originate from primitive mesenchymal cells capable of pluripotent differentiation; neoplastic cells have smooth muscle, neural, or dual differentiation. GIST is considered as a low-grade sarcoma arising from the interstitial cells of Cajal and harbouring mutation of c-kit. It may be demarcated, growing expansively, usually forming exophytic nodule on the serosal surface of the intestine, or it may be transmural and invasive. In our case, a nodule on the serosal surface was prominent but transmural growth of the tumour was present. GISTs are usually comprised of spindle cells arranged as interlacing fascicles or in a storiform pattern. A minority of cases may have somewhat epithelioid tumour cells arranged in trabecule or solid sheets, sometimes with a somewhat myxoid intercellular matrix. Epithelioid tumours are thought to reflect some degree of neural differentiation. Haemorrhage or necrosis may be present, and lymphocytic and/or eosinophilic infiltrates can occur. In our case, a part of the tumour consisted of tightly packed spindle cells arranged in interlacing fascicles, and in the remaining part epithelioid cells prevailed with slightly myxoid intercellular matrix. We did not find haemorrhages and necrotic foci but lymphocytic sheaths were observed around of some blood capillaries.

In humans GIST most commonly arises in the stomach $(51 \%)$, followed by the small intestine $(36 \%)$, colon (7\%) and rectum (1\%) or esophagus (1\%) (Tran et al. 2005). In domestic and farm animals GIST occurs predominantly in the intestine. Banerjee et al. (1991) described gastric stromal tumours in two Rhesus macaques (Macaca mulatta). Del Piero et al. (2001) diagnosed 11 GIST in 10 aged horses and one pony. Clinical signs were associated with two neoplasms $(22 \%)$; the remaining nine tumours were incidental findings at laparotomy or necropsy. Serosal or mural masses were located in the caecum (5), ileum (3), colon (2) and one in the stomach and in the jejunum. Histology revealed spindle cells arranged in fascicles and whorls or cribriform pattern with fascicles, often with myxoid interstitial matrix. Frost et al. (2003) described and analysed 29 GIST in dogs. The mean age of the animals was 11 years. Only $24 \%$ neoplasias were associated with clinical symptoms. Majority of the tumours were located in the large intestine. In the small intestine and stomach the GIST occurred with decreasing frequency. Histologically they were highly cellular spindles, less commonly epitheloid with mitotic rates from 0 to 19 per $10 \mathrm{HPF}$. In our guinea pig clinical symptoms were present, the tumour was located in the terminal part of the ileum, histologically it was similar to GISTs described in dogs, and rather high mitotic activity with numerous atypical figures was recorded. However, no metastases were found.

In human beings GISTs express in an overwhelming majority the tyrosine kinase KIT oncoprotein, having activating mutations in the KIT gene. However, around $10-15 \%$ 
of GIST lack KIT mutations and show absence of CD 117 expression as detected by immunohistochemistry, although chromosomal analysis showed losses of chromosomes 14,22 , and $1 \mathrm{p}$, which is a characteristic feature of GISTs (Debiec-Rychter et al. 2004). In a collection of 55 human GISTs by Romagnoli et al. (2005), CD117 was expressed in $96 \%$ tumours, CD34 was positive in $76 \%$ cases and the same quantity of neoplasias expressed both CD117 and CD34 antigens (Romagnoli et al. 2005). Ozcan et al. (2007) found some degree of expression of CD117, CD34, smooth muscle actin and Ki-67 in all 20 analyzed GISTs of humans. No case was reactive for desmin or S-100 protein. Feakins (2005) analyzed the expression of p53 and bcl-2 in human GISTs. Only positivity p53, but not bcl-2, showed association with the clinical outcome or risk category. Yamaguchi et al. (2003) proved that the prognosis of GIST in humans correlated with c-kit, Ki-67 and p53 positivity.

Although GISTs in animals are similar microscopically, they are a heterogeneous group of lesions via immunohistochemistry (Cooper nad Valentine 2002). Of 11 GISTs from horses three were S-100 protein positive, two were muscle actin positive, no neoplasms were positive for glial fibrillary acidic protein (GFAP), desmin, factor VIII, chromogranin, or neuron-specific enolase (Del Piero et al. 2001). In dogs, only 52\% were positive for CD117, none for desmin and S-100 protein (Frost et al. 2003). In our case the immunohistochemistry revealed positivity for actin, CD 117, neuronspecific enolase, GFAP and p53 protein; however, desmin, S100 protein and synaptophysin were negative. In literature, the results of GFAP examination are not given, with the exception of Del Piero et al. (2001). In contrast to horses, GFAP in our case was positive.

On the basis of histological and immunohistochemical examinations we diagnosed GIST in the terminal ileum in one guinea pig. Although morphological properties, marked mitotic activity and p53 positivity were indicators for malignancy, no metastases or generalisation were recorded.

\section{Gastrointestinální stromální tumor u morčete: kasuistické sdělení}

Předmětem př́ispěvku je popis př́ípadu gastrointestinálního stromálního tumoru (GIST) u morčete chovaného jako domácí miláček. Jednalo se o samce, 3,5 r. věku, trikolor. Přibližně po dobu pěti týdnů před smrtí zvíre hublo, navzdory dobré chuti k př́ijmu potravy, mělo sníženou motorickou aktivitu a trus byl měkký a páchnoucí. Morče uhynulo spontánně a při pitvě byl nalezen tumor šedorůžové barvy, velikosti vlašského ořechu lokalizovaný v terminálním ileu. Histologicky byl diagnostikován maligní tumor mesenchymálního charakteru. $\mathrm{V}$ jedné části vzorku byly vřetenité buňky uspořádané do vzájemně propletených svazků, $\mathrm{v}$ druhé části převládaly buňky epiteloidního vzhledu s mírně myxomatosní intercelulární matrix. Kolem některých kapilár byly lymfocytární pláště. Imunohistochemické vyšetření prokázalo přítomnost aktinu, CD117, neuron-specifické enolázy, gliálního fibrilárního kyselého proteinu a proteinu p53. Reakce na desmin, S100 protein a synaptofysin byly negativní. Na základě histologického a imunohistochemického vyšetření byl diagnostikován GIST.

\section{References}

Banerjee M, Lowenstine LJ, Munn RJ 1991: Gastric stromal tumors in two rhesus macaques (Macaca mulatta). Vet Pathol 28: 30-36

Brown CC, Baker DC, Barker IK 2007: Alimentary system. In: Maxie MG (Ed.): Jubb, Kennedy, and Palmer's pathology of domestic animals. Vol. 2. $5^{\text {th }}$ ed. Saunders Elsevier, Edinburgh-Toronto, pp.1-296

Cooper BJ, Valentine BA 2002: Tumors of muscle In: Meuten DJ (Ed.): Tumors in domestic animals. 4th ed. Iowa State Press, pp. 319-363

Debiec-Rychter M, Wasag B, Stul M, De Wever I, Van Oosterom A 2004: Gastrointestinal stromal tumours (GISTs) negative for KIT (CD 117 antigen) immunoreactivity. J Pathol 202: 430-438

Del Piero F, Summers BA, Cummings JF, Mandelli G, Blomme EA 2001: Gastrointestinal stromal tumors in equids. Vet Pathol 38: 689-697 
Feakins RM 2005: The expression of p53 and bcl-2 in gastrointestinal stromal tumours is associated with anatomical site, and p53 expression is associated with grade and clinical outcome. Histopathology 46: 270279

Frost D, Lasota J, Miettinen M 2003: Gastrointestinal stromal tumors and leiomyomas in the dog: a histopathologic, immunohistochemical, and molecular genetic study of 50 cases. Vet Pathol 40: 42-54

Hafner S, Harmon BG, King T 2001: Gastrointestinal stromal tumors of the equine cecum. Vet Pathol 38: 242246

Head KW, Cullen JM, Dubielzig RR, Else RW, Misdorp W, Patnaik AK, Tateyama S, Van der Gaag I 2003: Tumors of the alimentary system of domestic animals. Armed Forces Institute of Pathology, American Registry of Pathology, The World Health Organization Collaborating Center for Worldwide Reference on Comparative Oncology, Washington DC, $257 \mathrm{p}$.

Huizinga JD, Thuneberg L, Klüppel M, Malysz J, Mikkelsen HB, Bernstein A 1995: W/kit gene required for interstitial cells of Cajal and for intestinal pacemaker activity. Nature 373: 341-349

Iino S, Horiguchi K 2006: Interstitial cells of Cajal are involved in neurotransmission in the gastrointestinal tract. Acta Histochem Cytochem 39: 145-153

LaRock RG, Ginn PE 1997: Immunohistochemical staining characteristics of canine gastrointestinal stromal tumors. Vet Pathol 34: 303-311

Kobayashi S, Furness JB, Smith TK, Pompolo S 1989: Histological identification of the interstitial cells of Cajal in the guinea-pig small intestine. Arch Histol Cytol 52: 267-286

Lee HT, Henning GW, Fleming NW, Keef KD, Spencer NJ, Ward SM, Sanders KM, Smith TK 2007: Septal interstitial cells of Cajal conduct pacemaker activity to excite muscle bundles in human jejunum. Gastroenterology 133: 907-917

Mitsui R, Komuro T 2003: Distribution and ultrastructure of interstitial cells of Cajal in the gastric antrum of wild-type and Ws/Ws rats. Anat Embryol 206: 453-460

Ordög T, Ward SM, Sanders KM 1999: Interstitial cells of Cajal generate electrical slow waves in the murine stomach. J Physiol 518: 257-269

Ozcan A, Karshoglu Y, Kurt B, Onguru O, Gunhan O 2007: Quantitative evaluation if immunohistochemical staining in gastrintestinal stromal tumors. Anal Quant Cytol Histol 29: 159-165

Romagnoli S, Graziani D, Bramerio M, Gambacorta M, Colombo P, Roncalli M, Coggi G, Bosari S 2005: Immunohistochemical profile and c-kit mutations in gastrointestinal stromal tumors. Pathol Res Pract 201: 71-81

Sircar K, Hewlett BR, Huizinga JD, Chomeyko K, Berezin I, Riddell RH 1999: Interstitial cells of Cajal as precursor of gastrointestinal stromal tumors. Am J Surg Pathol 23: 377-389

Tran T, Davila J, El-Serag HB 2005: The epidemiology of malignant gastrointestinal stromal tumors: an analysis of 1,458 cases from 1992 to 2000. Am J Gastroenterol 100: 162-168

Ward SM, Burn AJ, Torihashi S, Sanders KM 1994: Mutation of the proto-oncogene c-kit blocks development of interstitial cells and electrical rhytmicity of murine intestine. J Physiol 4: 91-97

Yamaguchi M, Tate G, Endo Y, Miyaki M 2003: Immunohistochemistry and c-kit gene analysis in determining malignancy in gastrointestinal stromal tumors. Hepatogastroenterology 50: 1431-1435 
Plate IX

Jelínek F. et al.: Gastrointestinal ... pp. 287-291

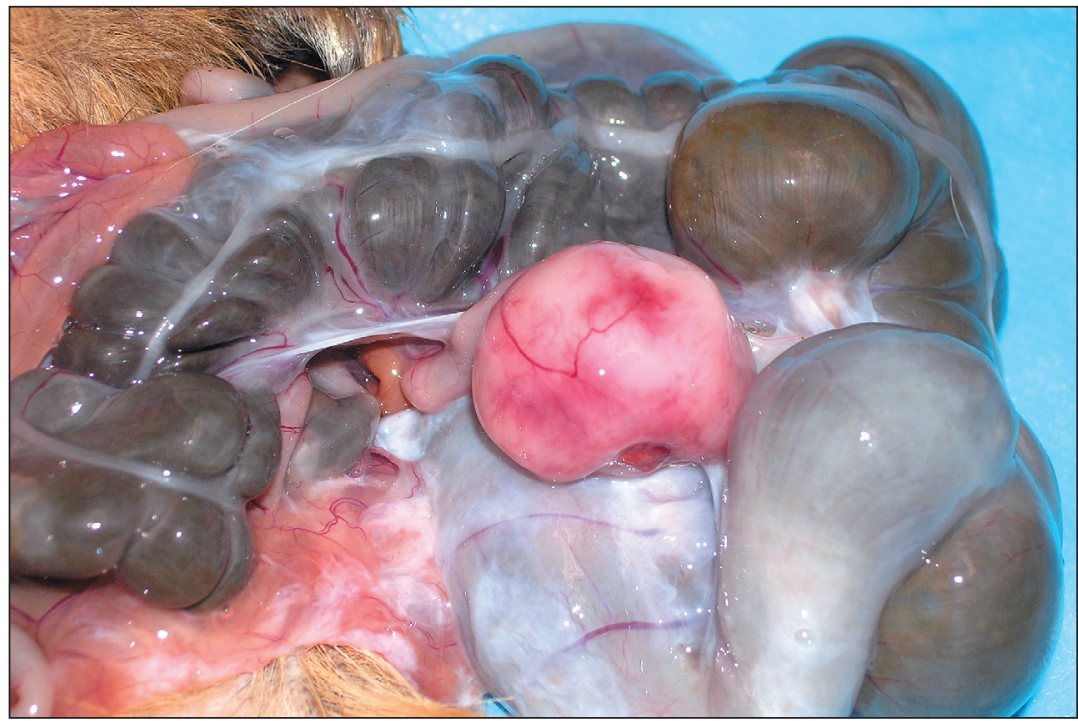

Fig. 1. Globoid tumourous formation located in the terminal segment of the small intestine

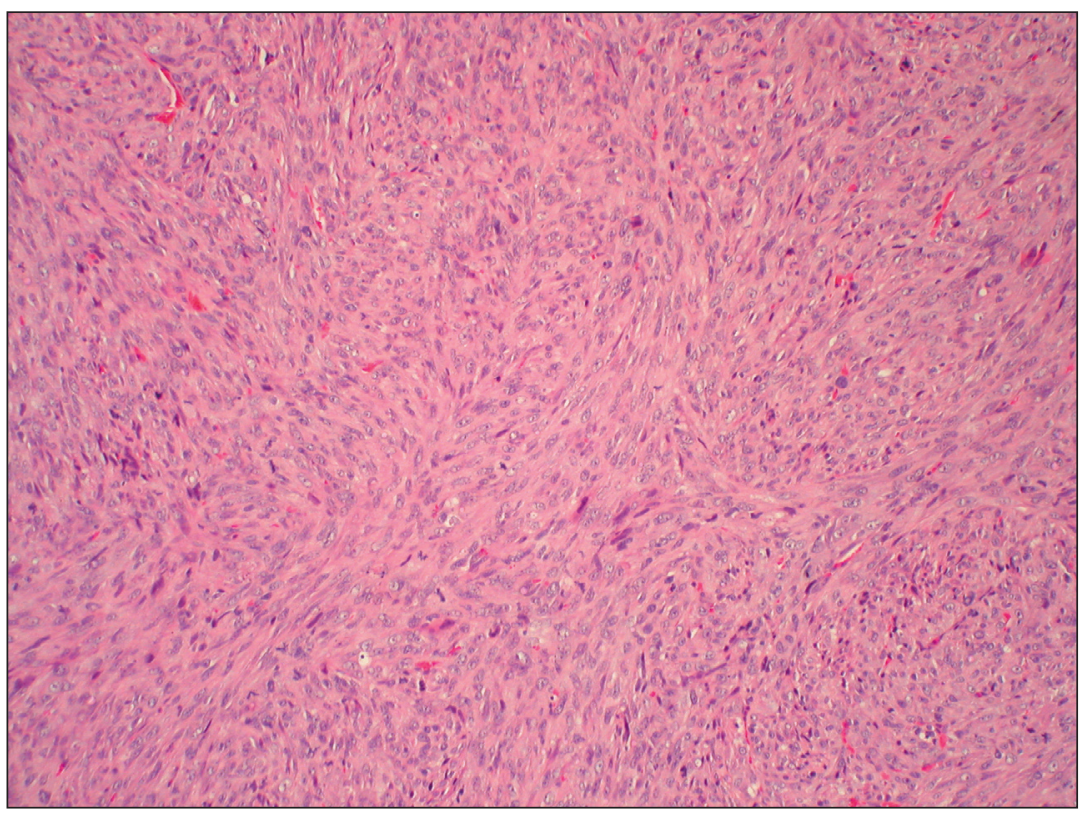

Fig. 2. Interlacing fascicles of spindle cells. Staining with haematoxylin and eosin, original magnification, $\times 40$ 


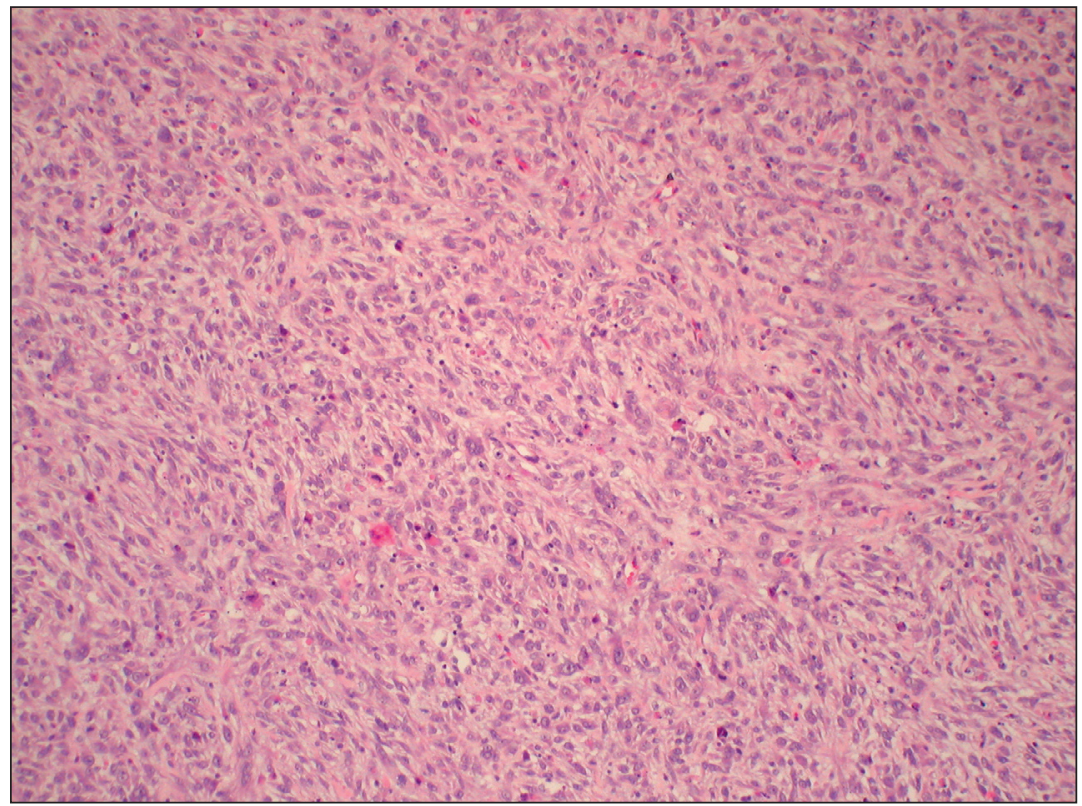

Fig. 3. Epithelioid cells with slightly myxoid intercellular matrix. Staining with haematoxylin and eosin, original magnification, $\times 40$

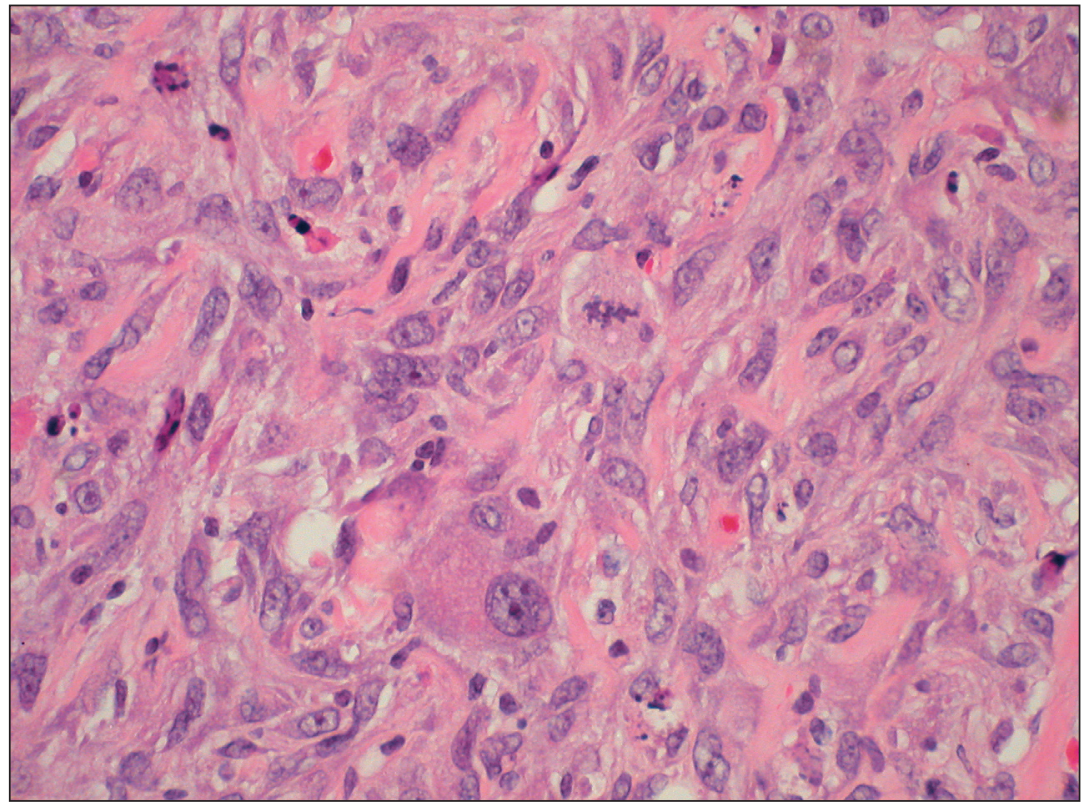

Fig. 4. Marked anisocytosis, anisokaryosis, mitotic figure (thick arrow), numerous apoptotic cells (thin arrows). Staining with haematoxylin and eosin, original magnification, $\times 160$ 


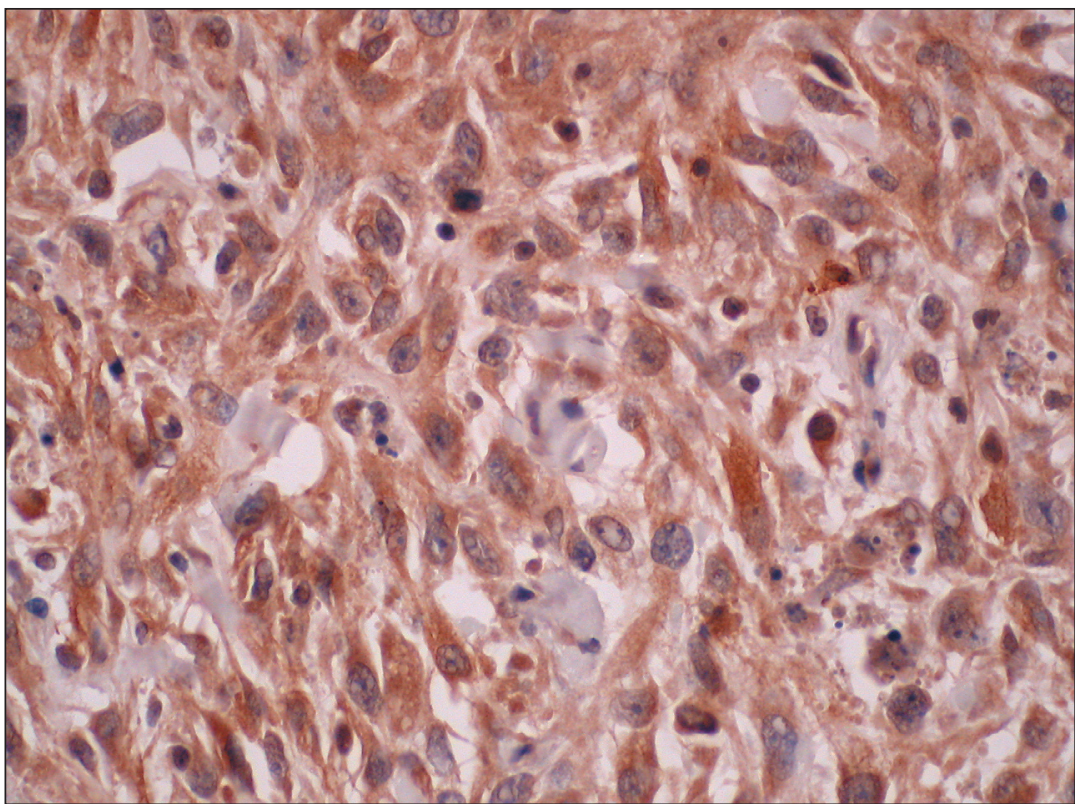

Fig. 5. Immunohistochemical reaction for CD 117 (c-kit). Positivity in cytoplasm of the

majority epithelioid neoplastic cells. Immunoperoxidase reaction, original magnification, $\times 160$

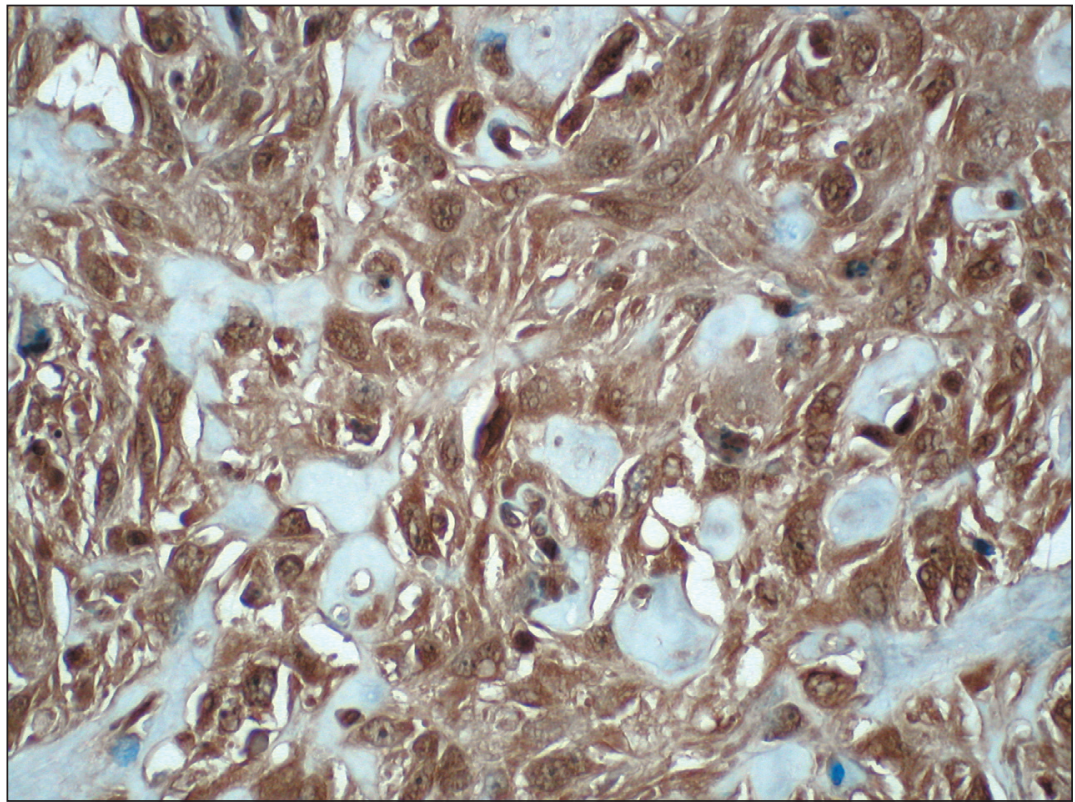

Fig. 6. Immunohistochemical reaction for GFAP. Positivity in cytoplasm of the majority epithelioid neoplastic cells. Immunoperoxidase reaction, original magnification, $\times 160$ 


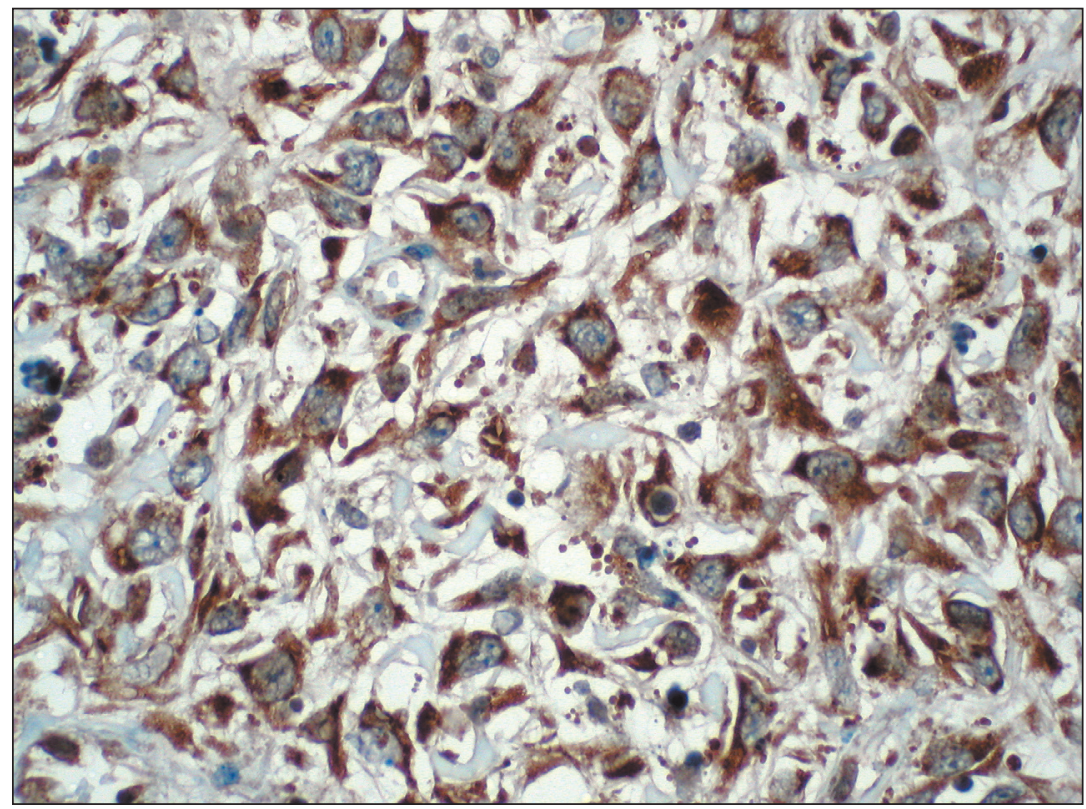

Fig. 7. Immunohistochemical reaction for neuronspecific enolase. Positivity in cytoplasm of the majority neoplastic cells. Immunoperoxidase reaction, original magnification,$\times 160$

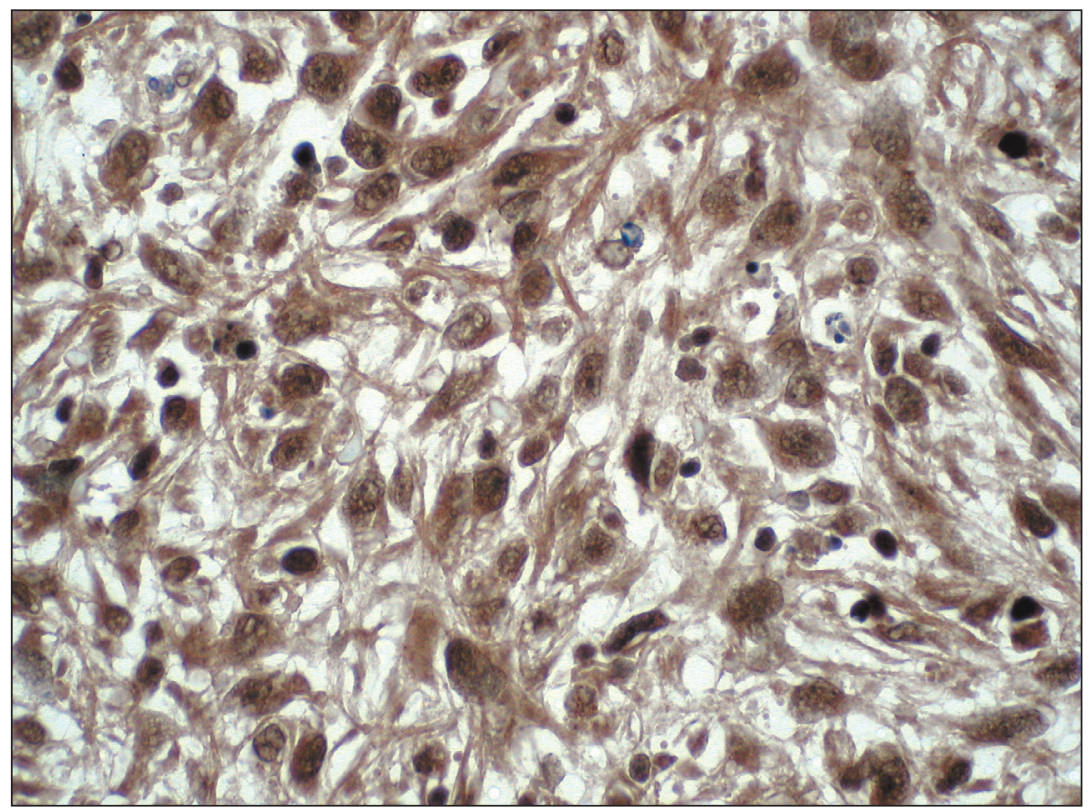

Fig. 8. Immunohistochemical reaction for p53 protein. Conspicuous reaction in the nuclei. Immunoperoxidase reaction, original magnification, $\times 160$ 